\title{
RELIGI RUWAT DALAM KIDUNG SUDAMALA
}

\author{
Ria Kasanova \& Sri Widjajanti \\ Prodi PBSI Fakultas Keguruan dan Ilmu Pendidikan \\ Universitas Madura \\ kasanovaria@gmail.com
}

\begin{abstract}
:
Java community has a form of customs that have systems such as values, norms, views and rules of life in society that embodies in the form of traditional ceremonies, to maintain harmony and harmony of the universe. In various forms of traditional ceremonies are still maintained to date, such as the salvation of birth, death, descend, and others. One of the traditional rituals of Javanese society is still done is ruwatan ceremony. Sudamala is a famous ruwat story in the final days of the majapahit kingdom. The method of this research is analytical description method. This study aims to find what is contained in the song Sudamala through data analysis activities followed by then drawn conclusions. Next is to make the tangible text description. Based on the above discussion can be found forms of religious systems that are written in it, namely; religious emotions, belief systems, and religious people.
\end{abstract}

Keywords: religion, ruwat.

\section{Pendahuluan}

Masyarakat jawa memiliki wujud adat istiadat yang memiliki sistem seperti tata nilai, tata norma, pemikiran pandangan serta aturan kehidupan di dalam masyarakat yang wujudkan dalam wujud upacara tradisi, untuk menjaga harmonisasi dan keserasian semesta. Dalam berbagai wujud upacara yang tradisional tersebut masih dipertahankan sampai saat ini, seperti selamatan kelahiran, kematian, turun tanah, dan lainnya. Salah satu wujud upacara tradisional masyarakat jawa yang masih dilakukan adalah upacara ruwatan.

Istilah ngruwat, koentjaraningrat ${ }^{1}$ menjelaskan bahwa upacara ngruwat adalah upacara khas agami jawa atau biasa disebut agama jawi. Yang bertujuan untuk melindungi anak terhadap bahaya yang bersifat gaib yang disimbolkan oleh tokoh seorang bhatara yaitu bathara kala, yang menjadi dewa kehancuran. Berbagai jenis kompilasi dalam sebuah keluarga yang dianggap sangat berbahaya, yang menyebabkan anak-anak yang perlu diruwat tersebut rentan terkena penyakit, bahaya, dan kematian, disebabkan mereka menjadi umpan dari bathara kala tersebut. Upacara meruruwat juga perlu diadakan jika terjadi peristiwa yang

${ }^{1}$ Koentjaraningrat. Sejarah Teori Antropologi I. (Jakarta: UI-Press. 1994) 312 
dapat menyebabkan bahaya, seperti jika batu penggiling rempah-rempah atau periuk yang digunakan untuk memasak nasi jatuh ataupun pecah.

Istilah kata ruwatan memiliki asal dari kata ruwat yang memiliki arti bebas atau lepas ${ }^{2}$. Definisi ini didukung oleh penjelasan Darmoko ${ }^{3}$ yang menyatakan bahawa kata ruwatan memiliki asal dari kata ruwat yang bersufiks -an. Kata ruwat itu mengalami gejala bahasa, yakni berasal dari kata luar, yang memiliki arti terbebas ataupun terlepas.

Di dalam upacara ruwat, biasanya ditampilkan sebuah pertunjukan pentas wayang. Lakon yang sering dimainkan pun adalah lakon ruwatan. Lakon yang sering dimainkan pada upacara ruwatan yaitu lakon murwakala yang biasanya berkisah tentang kelahiran dewa atau batara kala. Kisah tersebut didapat dalam kesusastraan jawa. Menurut Poerbatjaraka ${ }^{4}$, kitab manikmaya ditulis pada masa kartasura oleh kartamursadah, sedang serat paramayoga ditulis oleh raden ngabehi ranggawarsita. Pada kedua karya tersebut ada bagian yang bercerita mengenai kelahiran sang batara kala.

Kedua kisah pada kitab tersebut mengisahkan sang batara guru yang tidak dapat menahan berahinya terhadap sang batari uma saat sedang mengelilingi dunia. Namun, hasrat itu tidak diterima oleh istrinya sehingga kama (sperma) nya keluar dan kemudian jatuh ke samudra. Kama yang jatuh kemudian berubah menjadi buta atau raksasa yang kemudian dinamakan batara kala. Saat kelahiran batara kala menggetarkan kahyangan. Batara kala menuju kahyangan untuk menemui batara guru dan menanyakan siapa ayahnya. Batara guru kemudian memberi tahu bahwa sebenarnya dialah ayahnya kemudian menempatkannya di pulau nusakambangan untuk menjadi raja para mahluk halus. Sang batara kala menyanggupi dengan syarat diberikan jatah makanan. Kemudian oleh ayahnya, yaitu batara kala diberikan jatah makanan yaitu orang sukerta dan anak-anak ${ }^{5}$.

Orang sukerta atau anak-anak memiliki cacat cela yang menjadi bawaan lahir dan menurut kepercayaan masyarakat turun temurun, mereka tersebut menjadi jatah makanan batara kala, dewa raksasa yang ditugaskan merajai makhluk halus yaitu, setan, peri prayangan,hantu, banaspati, ilu-ilu, dan sebagainya. Orang-orang yang dijadikan jatah makan sang batara kala dianggap memiliki hidup yang sengsara, maka harus dilepaskan dari kesengsaraan tersebut ${ }^{6}$. Namun, hal tersebut bisa dicegah dengan melakukan sebuah upacara ruwatan. Tujuan diadakannya upacara ruwatan yaitu agar seseorang yang sedang "diruwat" bisa terlepas atau terbebas dari marabahaya (malapetaka) yang melingkupinya7.

\footnotetext{
2 Kamajaya, H. Karkono. Ruwatan Murwakala: Sebuah Tinjauan. (Yogyakarta: Duta Wacana University Press.1992) 10

3 Darmoko. Pedoman Pewayangan Berspektif Perlindungan Saksi Dan Korban (Jakarta.LPSK.2003) 24

${ }^{4}$ Poerbatjaraka Agastya di Nusantara. (Jakarta. Yayasan Obor Indonesia.1986) 132

5 Kamajaya, H. Karkono. Ruwatan Murwakala: Sebuah Tinjauan. (Yogyakarta: Duta Wacana University Press.1992) 13-23.

${ }^{6}$ Kamajaya, H. Karkono. Ruwatan Murwakala: Sebuah Tinjauan. (Yogyakarta: Duta Wacana University Press.1992) 35

7 Darmoko. Pedoman Pewayangan Berspektif Perlindungan Saksi Dan Korban (Jakarta.LPSK.2003) 27
} 
Jika pada kisah ruwat dalam karya sastra di atas tergolong dalam kesusastraan jawa baru, yang diruwat adalah orang yang terkena sukerta dan anak-anak, namun kisah ruwat kesusastraan jawa kuna yang diruwat yaitu dewa atau dewi yang sedang dikutuk menjadi raksasi dan raksasa kemudian yang meruwat juga adalah dewa atau manusia titisan dewa. Salah satu contoh kisah ruwat dari budaya jawa kuna, yaitu kidung Sudamala.

Sudamala adalah kisah ruwat yang dikenal pada masa-masa akhir kerajaan majapahit. Jika dikaji secara etimologis, istilah Sudamala berasal dari kosa kata bahasa jawa kuno yang kemudian dibentuk oleh kosa kata śuddha dan mala. Śuddha memiliki 'bersih; suci, sedangkan kata mala memiliki arti 'kotor(an); noda;

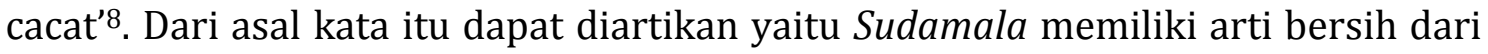
kotoran atau. Jika kemudian dihubungkan dengan ceritanya, maka nama Sudamala, yang dijadikan tokoh utama dalam kisah Sudamala, adalah seseorang yang mampu membersihkan kotoran atau orang yang meruwat.

Zoetmulder ${ }^{9}$ mengatakan dalam kalangwan, penuturan dalam bentuk lisan rupanya sangat berperan besar di dalam sejarah terbentuknya teks- teks dalam kidung Sudamala seperti yang dapat dilihat dari segi keragaman mengenai isi maupun ejaannya. Zoetmulder juga menambahkan mengenai asal-usul mengenai prototipe teks dari kidung Sudamala sebaiknya dicari di banyuwangi yang telah ada pada abad ke-17 hingga sampai pada abad ke-18 adalah bagian dari kerajaan blambangan, yang merupakan kerajaan jawa-hindu terakhir di pulau jawa, namun demikian ceritanya telah diketahui jauh sebelumnya.

Cerita tentang Sudamala yang telah berkembang dari berbagai tradisi lisan tersebut disusun menjadi karya yang berwujud kidung. Di dalam kidung Sudamala tidak pernah ditemukan nama penulisnya juga tidak didapat informasi mengenai waktu penciptaan atau penyusunannya berlangsung. Selain berbentuk karya sastra, kisah tersebut dipahat menjadi relief candi seperti salah satunya yaitu candi sukuh. Berdasarkan hal tersebut, maka penulis tertarik untuk menelaah sistem religi dalam kidung Sudamala

\section{METODE PENELITIAN}

Metode penelitian ini yaitu metode deskripsi analisis. Penelitian ini bertujuan untuk mencari apa yang terkandung di dalam kidung Sudamala melalui kegiatan analisis data yang dilanjutkan dengan kemudian ditarik simpulan. Selanjutnya adalah membuat tulisan yang berwujud deskripsi.

Kidung Sudamala memiliki sistem religi. Sebagai sebuah karya dan juga sesuatu yang selalu diyakini, kidung Sudamala sebenarnya adalah wujud budayasalah satu wujud budaya tersebut adalah sistem religi, sistem religi yang dimaksud memiliki lima komponen yang ada pada setiap bentuk kebudayaan. Kelima komponen itu adalah; emosi keagamaan, sistem keyakinan, sistem ritus dan upacara, peralatan ritus dan upacara, dan umat agama ${ }^{10}$ (Koentjaraningrat, 1981: 80). Data pembahasan ini bersumber dari sumber data yang telah diolah kemudian dikumpulkan dan dianalisis dengan mengelompokkan-nya menjadi lima

\footnotetext{
${ }^{8}$ Mardiwarsito. Arjuna Wiwaha.(Jakarta .Duta Wacana. 1990) 70

${ }^{9}$ Zoetmulder. Manunggaling Kawula Gusti: panteisme dan monisme dalam suluk sastra jawa. Suatu studi filsafat. Terjemahan Dick Hartoko (Jakarta: PT Gramedia.1983) 540

${ }^{10}$ Koentjaraningrat. Sejarah Teori Antropologi I.( Jakarta: UI-Press 1981) 80
} 
bagian didasarkan kelima fokus pembahasan di atas. Teks data yang akan digunakan bersumber dari data teks kidung Sudamala. Setelah analisis maka dapat mengetahui apakah kisah kidung ruwat Sudamala mengandung sistem religi.

\section{PEMBAHASAN}

\section{Religi dalam Kidung Ruwat Sudamala a. Emosi Keagamaan}

Religiusitas proses ruwatan dalam Kidung Sudamala merupakan kepercayaan terhadap sakralitas ruwat yang diyakini dapat melepaskan seseorang dari derita atau dosa, Seperti yang dilakukan oleh Sadewa, salah satu dari anggota Pandawa yang dipilih untuk meruwat dewi Uma, yang menjadi dewi Durga. Emosi keagamaan yang timbul adalah berupa getaran jiwa yang memunculkan sikap religius. Dari sikap religius itu berupa perasaan, hormat, kagum, dan takut terhadap fenomena di luar dirinya. Hal tersebut tercermin dari kutipan teks di bawah ini;

Hyang Guru kini turun ke dunia manusia. Ia masuk ke setra gondomayit, dan berkatalah hyang guru itu"Sadewa, jangan kamu khawatir. Lepaskanlah hyang huma. Caranya, aku akan masuk ke dalam badanmu."

Emosi kegamaan yang muncul dalam teks Kidung Sudamala tampak dengan perasaan haru ketika Sudamala yang merupakan seorang ksatria bagian dari pandawa tidak mampu meruwat Dewi Uma, dan mendapatkan ancaman akan dibunuh jika Sudamala tetap menolah meruwat Dewi Uma, maka untuk meyelamatkan Sadewa, Batara Guru sendirilah yang turun ke bumi untuk menyelamatkan jiwa Sadewa serta memberikan kekuatan kepada Sadewa untuk meruwat Dewi Uma. Fenomena luar biasa ini merupakan sesuatu yang diluar kemampuan manusia untuk menyaksikan hal yang sangat fantastis sekaligus luar biasa, hal ini menyiratkan sebuah makna mendalam bahwa seseorang yang bersih, suci, jujur, dan berwatak ksatria akan senantiasa mendapatkan pertolongan dari dewa untuk melaksanakan hajatnya.

Di tengah alam yang menyeramkan itu hyang guru masuk ke dalam badan sadewa. Kini sadewa sanggup melakukan ruwat, melepaskan sang dewi uma. Satria ini berkata "hamba si sadewa, akan melepaskan paduka hyang. Hamba mohon maaf sebelumnya" (Sukahar, 2013: 140)

Sadewa dalam melaksanakan hajatnya yaitu melakukan ruwatan untuk membebaskan dewi Uma, tidak dapat melakukan sendiri, karena ia hanya manusia biasa, sedangkan Batari Durga atau Dewi Uma yang sedang mengalami kutukan merupakan seorang dewi kahyangan tertinggi istri batara guru, maka demikian, batara guru turun tangan langsung turun ke bumi untuk membantu Sadewa atau Sudamala dengan masuk kedalam tubuhnya untuk membebaskan dewi durga dari noda, kemudian dimulalah prosesi ruwatan yang tidak lazim tersebut, karena yang diruwat adalah seorang dewi, bukan manusia biasa. Hal ini menimbulkan emosi keagamaan yang mendalam bahwa manusia juga dapat memberikan ruwatan kepada dewa atau dewi yang sedang berada dalam kesialan.

. Prosesi ruwat merupakan prosesi yang suci dan sakral, karena dalam prosesi ini melibatkan beberapa aspek yaitu selain kemampuan untuk meruwat, sesajian, serta kemantapan hati untuk menentramkan dan menenangkan 
seseorang yang akan diruwat. Ruwatan merupakkan prosesi suci dan sakral karena hanya bisa dilakukan oleh orang-orang tertentu yang dianggap suci untuk mengangkat derita atau noda orang-orang yang sering mengalami kesialan.

Raden Sadewa kini mendekati Hyang dewi. Ia menentramkan hatinya.

Tak lama setelah itu Hyang Ayu mendengar mantra Hung-kara diucapkan sadewa. Dilantunkan dengan merdu. Suaranya menggema ke langit tertinggi. Mengusik seisi jagad raya (Sukahar, 2013: 141)

Emosi keagamaan pada teks di atas pada intinya menceritakan keadaan yang muncul atau timbul ketika raden sadewa membacakan mantra Hung-Kara yang menimbulkan suasana tenteram di hati Dewi Durga, serta lantunan suaranya menggema terdengar sampai seisi jaga raya mendengar suaranya lantunan mantra untuk meruwat Dewi Durga.

Setelah itu ia mengambil beras kuning. Beras itu ditaburkan bersamaan dengan bunga tabur. Ia menebarkan ke tubuh ranini. Tak lama ranini pun menjerit, ia melengking panjang. Setelah itu ia terdiam dengan tubuh lunglai, dan terlepaslah wujud durganya. (Sukahar, 2013: 141)

Ranini berganti rupa. Ia kembali menjadi Hyang Ayu yang cantrik jelita. Penglihatannya menjadi terang. Cuaca kembali benderang. Ia menengadah. Melihat hujan turun rintik-tintik. Diikuti angin sepoi-sepoi basah sampai matahari tenggelam. (Sukahar, 2013: 141)

Suasana sakral yang tampak pada teks di atas mengungkapkan keadaan Dewi Durga yang tengah diruwat oleh raden sadewa dengan merapalkan mantra hung-kara dan menebarkan beras kuning serta bunga ke tubuh dewi Durga, yang kemudian menimbulkan efek tubuh dewi durga yang mengejang dan melengking panjang dan terdiam, kemudian terlepas wujudnya, wujud sosok raksasa perempuan yang menyeramkan kembali menjadi seorang hyang ayu atau dewi uma, seorang dewi yang berparas cantik. Suasana sakral tersebut tampak pada prosesi yang dilakukan oleh raden sadewa yang menimbulkan respek yang dan dilanjutkan dengan perubahan seorang batahara durga, sosok raksasa jahat kemudian menjadi seorang dewi yang cantik jelita.

\section{b. Sistem Keyakinan}

Sistem keyakinan yang terdapat teks kidung Sudamala adalah keyakinan mengenai keberadaan makhluk halus. dalam masyarakat jawa ini memiliki keyakinan tertentu terhadap jin, roh, setan, dan raksasa. Koentjaraningrat 11 (1984: 339) menjelaskan bahwa mahluk-mahluk tersebut pada umumnya selalu dianggap jahat, dan oleh masyarakat jawa disebut memedi. khususnya mereka yang disebut setan, sedangkan golongan raksasa disebut dengan denawa atau buta. masyarakat jawa mengenal banyak roh-roh jahat daripada roh-roh yang baik, namun mengenai hal tersebut mereka juga memiliki pendapat-pendapat yang sering bertentangan.

Penjelasan tersebut atas telah diketahui terdapat dua penggolongan makhlus halus, yakni yang memiliki sifat baik dan yang memilikisifat jahat. jenis makhluk halus yang memiliki sifat baik biasanya adalah roh yang menjadi pelindung desa yang dipercayai sebagai wujud roh leluhur. biasanya mereka ini disebut dengan istilah dhanyang. sedangkan makhluk yang digolongkan jahat

${ }^{11}$ Koentjaraningrat ${ }^{11}$ (1984: 339) 
wujudnya dapat bermacam-macam sesuai sebutan yang beragam pula, seperti jenis buta dan dhemit.

Perubahan Ranini kembali menjadi Hyang Ayu itu juga disusul dengan perubahan para hantu. Yang perempuan menjadi bidadari, yang laki-laki menjadi bidadara. Kerajaan setra kini pun tak menakutkan lagi. Kerajaan itu menjadi taman bunga, sangat indah, penuh dengan bunga aneka warna. Asoka sedang berkembang sangat eloknya. Ditempat penjuru taman terdapat balai tajuk. Di tengah-tengah terdapat kolam pemandian. (Sukahar, 2013: 141)

Sistem keyakinan dalam kutipan teks di atas ditunjukkan dengan adanya sebuah proses yang terjadi secara berurutan yaitu ketika proses ruwat telah berhasil mengembalikan sosok ranini atau Batahari Durga, maka secara berurutan diikuti dengan perubahan hantu-hantu yang ikut berubah. Hantu perempuan menjadi bidadari, dan hantu laki-laki menjadi bidadara, serta dilanjutkan dengan perubahan hutan gondomayit yang ikut juga berubah menjadi sebuah taman yang indah. Hal ini menunjukkan sebuah sistem religi bahwa perubahan terhadap seseorang akan diikutsertai dengan perubahan sekelilingnya.

Hyang ayu menundukkan kepala dan memandang ke permukaan kolam, bercermin dan melihat, bahwa ia sekarang telah kembali cantik jelita. "ah, kini sungguh sudah terlepas dari noda." Begitu ungkapnya, yang disuarakan dengan manis dan perlahan-lahan. (Sukahar, 2013: 141)

Sistem keyakinan yang dimunculkan dengan teks di atas terihat dengan adanya perubahan yang terjadi pada dewi durga akibat proses ruwat yang dilakukan oleh Sadewa. Perubahan pada wujud ranini yang semula berwujud sebagai raksasa perempuan berubah pada wujud semula yaitu menjadi Hyang Ayu, maka fenomena ini bukan hanya menunjukkan perubahan wujud fisik semata, namun lebih dari itu, perubahan wujud ranini atau bathari durga juga menandari hilangnya noda atau hilangnya dosa atau dengan kata lain telah terlepasnya kutukan yang dialami oleh dewi durga dengan disucikan atau diruwat dari dosadosanya yang lampau.

\section{c. Umat Agama}

Umat agama merupakan kesatuan umat dalam menjalankan suatu proses ritual agama atau dalam keadaan sedang menjalani prosesi ritual keagamaan. Dalam kidung ruwat Sudamala, diceritakan bahwa Sudamala yang telah berhasil meruwat Hyang Durga atau Ranini yang kemudian telah menjadi Hyang Uma.

"wahai, manusia sadewa, sekarang aku sudah terlepas dari derita. Aku sangat berutang budi padamu, sadewa. Sadewa kamu kini saya angkat menjadi putraku. Kuganti namamu menjadi Sudamala, karena kamu sudah melepaskan aku dari malapetaka, dan kamu juga telah terlepas dari segala dosa, selamat selanjutnya" (Sukahar, 2013: 142)

Kutipan data tersebut menunjukkan adanya sistem religi dalam konteks umat agama, yaitu kesatuan umat yang ditunjukkan oleh tokoh Sadewa dan juga Hyang Uma yang menjadi satu kesatuan umat ketika tokoh Sadewa berhasil melepaskan derita Hyang Durga kemudian kembali menjadi Hyang Uma, selain itu 
kesatuan umat agama juga tampak ketika Sadewa menerima penghargaan dan anugerah dari Hyang Uma berupa nama Sudamala yang memiliki arti melepaskan derita. Pemberian anugerah dan penerimaan anugerah pada umumnya hanya dilakukan pada kesatuan yang sama, baik dalam konteks agama, komunitas, atau pun insttitusi.

Kini telah lepas hyang Dewi, telah kembali naik ke surga. Beliau bersabda pada waktu itu: "kamu telah melepaskan aku dari derita. Sekarang ada seorang bernama Tmbakpetra. Ia menderita sakit. Hendaknya di aku lepaskan juga. Di daerah timur laut tempat tinggal tambakpetra itu, ia menderita sakit buta. Punya dua orang dara dan masih-masih, cantik-cantik, ambillah semua! Begitu sabda Hyang Ayu" (Sukahar, 2013: 148)

Secara umum teks di atas menceritakan tentang Sudamala yang diberikan perintah oleh Hyang Dewi Uma. Sudamala mendapatkan perintah untuk berjalan dan menemukan Begawan Tambapetra yang sedang sakit untuk disembuhkan. Selain itu juga untuk mengambil anak-anak Begawan Tambapetra sebagai istri yaitu $\mathrm{Ni}$ Soka serta saudaranya Ni Padapa. Walaupun pada akhirnya hanya Ni Padapa yang menjadi istri Sudamala karena saudarinya, Ni Soka diberikan kepada kakaknya yaitu Sakula. Peristiwa perjodohan dan penyembuhan dalam prosesi ruwat ini merupakan bentuk sistem religi dalam konteks umat agama, yaitu kesatuan umat yang berada dalam satu hubungan spiritual agama.

\section{Kesimpulan}

Berdasarkan pembahasan di atas dapat ditemukan bentuk-bentuk sistem religi yang tersurat di dalamnya, yakni; emosi keagamaan, sistem keyakinan, dan umat agama.

\section{Daftar Pustaka}

Darmoko. 2003. Pedoman Pewayangan Berspektif Perlindungan Saksi Dan Korban Jakarta.LPSK.

Kamajaya, H. Karkono. 1992. Ruwatan Murwakala: Sebuah Tinjauan. Yogyakarta: Duta Wacana University Press.

Koentjaraningrat. 1994. Sejarah Teori Antropologi I. Jakarta: UI-Press.

Koentjaraningrat. 1981. Sejarah Teori Antropologi I. Jakarta: UI-Press.

Poerbatjaraka.1986. Agastya di Nusantara. Jakarta. Yayasan Obor Indonesia.

Mardiwarsito. 1990. Arjuna Wiwaha.Jakarta .Duta Wacana.

Zoetmulder. 1983. Manunggaling Kawula Gusti: panteisme dan monisme dalam suluk sastra jawa. Suatu studi filsafat. Terjemahan Dick Hartoko Jakarta: PT Gramedia. 